\title{
Flood Inundation Mapping of Babai Basin using HEC-RAS \& GIS
}

\author{
Pawan Bhattarai, Prajwal Khanal, Prachanda Tiwari, Nischal Lamichhane, \\ Prasanna Dhakal, Prakash Lamichhane, Nirajan Raj Panta, Prashant Dahal \\ Department of Civil Engineering, Pulchowk Campus, Institute of Engineering \\ Tribhuvan University, Kathmandu, Nepal \\ *Corresponding author: prajzwal8842@gmail.com
}

Received: Oct 13, 2018

Revised: April 27, 2019

Accepted: May 4, 2019

\begin{abstract}
The main objective of this research is to prepare inundation map of a section of Babai Basin and to find out the inundated areas for different return periods. In order to achieve the objectives, Geographic Information System (GIS) and HEC-RAS along with HEC-GeoRAS extension were used as tools. Coordinates were used as primary parameter and were obtained from survey to generate geometric data such as Triangular Irregular Networks (TIN), streamline, river bank and flow paths. After importing the geometry data into HEC-RAS, hydraulic modelling was applied by using flow data as main input. As a result, the watershed area of the Babai basin has been successfully modelled and map showing the flooded areas along the Babai basin has been delineated. The flooded area was geometrically overlaid on the topographic map to outline the affected areas. The area under the influence of the flood were assessed which shows that about $49 \%$ of total inundated areas comprises farming land. Also a sensitivity analysis was performed to predict the change in percentage of flooded areas when Maning's parameter was increased by $10 \%$ and when kept same in both banks and channel. However, differences in figure of inundated areas are insignificant to variations made in Maning's n.
\end{abstract}

Keywords: Inundation, GIS, HEC-RAS, flood

\section{Introduction}

Flooding is an overflow of a large amount of water from river beyond its normal limits. Immense water resources on Nepal has on one hand a promise of wealth and huge development potential and on the other hand, frequently loom over to people and the environment as threat and menace. Every year during the monsoon, many villages on river bank have to bear with major flood problem caused mainly by heavy rainfall and compounded by degraded environment. Flooded river carry heavy load of sediments causing erosion, damaging crops, destroying private and communal properties and infrastructures and threatening the survival of many villages. Therefore, flood analysis has become very important for safety of many communities. 
Identification and mapping of flood prone areas are valuable for risk reduction. Flood mapping consists of modeling the complex system of river flow hydraulics using HECRAS and mapping the resulting the output in GIS. HEC-RAS models play a pivotal role in these analyses by aiding in the determination of water surface profiles associated with different flow conditions. Unfortunately, a consistent deficiency of these programs has been their inability to connect the information describing the water profiles with their physical locations on the land surface. Often the computed water surface elevations are manually plotted on paper maps in order to delineate floodplains. Automating this manual plotting would result in significant savings of both time and resources. Geographic information systems (GISs) offer the ideal environment for this type of work.

Study Area: The location of study area was near about $40 \mathrm{~km}$ south of Babai Bridge in Ratna Rajmarga near Purandhara, Dang. Dang is located in Inner Terai, around $410 \mathrm{~km}$ west of capital city, Kathmandu. Purandhara is a small town bordering Dang from Salyan. Study site of the project is located about $2 \mathrm{~km}$ SE from Purandhara. The coordinate of outlet of the reach of study area is 28.171721 N, 82.067482 E. (Source: Google Earth). The Babai River originates in the Churia (Siwalik) range in Nepal, and flows westwards before it confluents with the Karnali River south of the Nepal-India border.

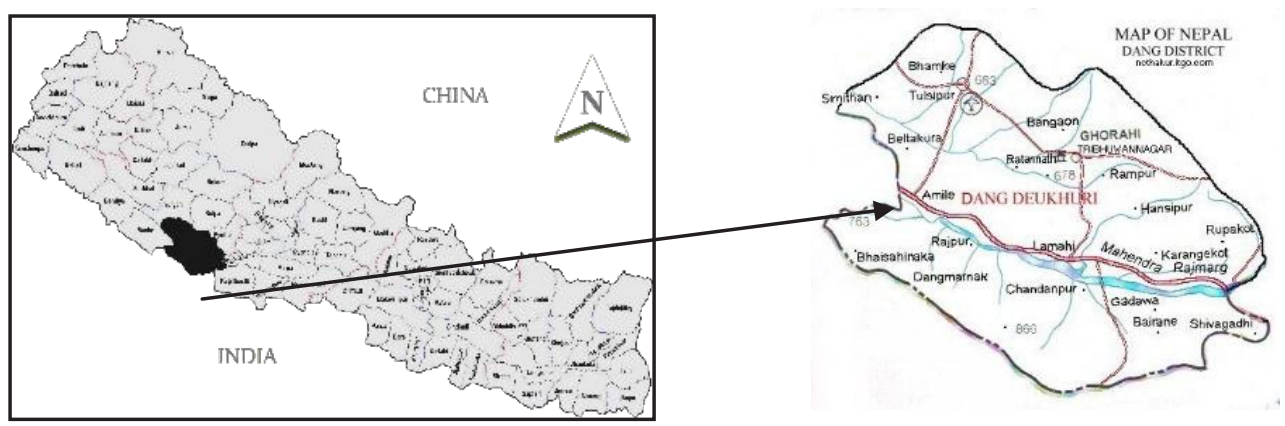

Fig. 1: Location map of study area Source: $h t t p: / / w w w . i n s e c o n l i n e . o r g$

\section{Literature Review}

\subsection{Flood Method Analysis and Methods}

High floods are required to be computed for HEC-RAS modelling as HEC-RAS needs discharge as input to find out flood inundation depths for various return periods. The flood flow analyses are carried out to obtain the worst flood that can occur in different time. Reliable flood estimates are essential for preparing flood hazard map of any basin. These flood estimates can be done via different methods which are depicted hereby:

\subsubsection{WECS/DHM Method [10]}

In Nepalese context, Water and Energy Commission Secretariat (WECS)/Department of Hydrology and Meteorology (DHM) have developed empirical relationships for analyzing flood 
of different frequencies. Using this method, 2-year and 100-year floods for maximum daily and maximum instantaneous flood peaks shall be computed from regression equation of the form:

$$
Q_{T}=\alpha\left(A_{3000}+1\right)^{\beta}
$$

where, $Q_{\mathrm{T}}$ is the discharge in $\mathrm{m}^{3} / \mathrm{s}, \mathrm{A}_{3000}$ is the basin area in $\mathrm{km}^{2}$ below $3000 \mathrm{~m}$ elevation. Constants $\alpha$ and $\beta$ have different values for 2-year and 100-year return period.

$$
\alpha=\left\{\begin{array}{l}
1.8767 \text { for } 2-\text { year } \\
14.63 \text { for } 100-\text { year }
\end{array} \quad \beta=\left\{\begin{array}{c}
0.8783 \text { for } 2-\text { year } \\
0.7342 \text { for } 100-\text { year }
\end{array}\right.\right.
$$

For other return periods, $\quad Q_{T}=e^{\left(\ln Q_{2}+S \sigma\right)}$

where, $\mathrm{Q}_{\mathrm{T}}$ is flood discharge for different return periods in $\mathrm{m}^{3} / \mathrm{s}$,

$$
\mathrm{S} \text { is standard normal variate } \sigma=\frac{\ln \frac{Q_{100}}{Q_{3}}}{2.326}
$$

Table 1: Value of S corresponding to $\mathrm{T}$

\begin{tabular}{|c|c|c|c|c|c|c|c|c|c|}
\hline $\mathbf{T}$ & 2 & 5 & 10 & 25 & 50 & 100 & 500 & 100000 & 10000 \\
\hline $\mathbf{S}$ & 0 & 0.842 & 1.282 & 1.645 & 2.054 & 2.326 & 2.878 & 3.09 & 3.719 \\
\hline
\end{tabular}

\subsubsection{Rational Method [7]}

The peak value of runoff is given by $Q_{p}=\frac{1}{3.6} C\left(i_{t_{c} p}\right) A$ for $t \geq t_{c}$

where $\mathrm{Q}_{\mathrm{p}}=$ peak discharge $\left(\mathrm{m}^{3} / \mathrm{s}\right), \mathrm{C}=$ coefficient of runoff $=$ runoff $/$ rainfall, $i_{t c, p}=$ mean intensity of precipitation $(\mathrm{mm} / \mathrm{h})$ for duration equal to $t=t_{c}$ and exceedance probability $\mathrm{P}, \mathrm{A}=$ Area of drainage in $\mathrm{km}^{2}$

\subsubsection{Gumbel's Method [7]}

Gumbel defined flood as the largest of the 365 daily flows and the annual series of flood flows constitute a series of largest values of flows. According to his theory of extreme events, the probability of occurrence of an event equal to or larger than a value of $x_{0}$.

The value of variate $\mathrm{X}$ with a recurrence interval $\mathrm{T}$ is used as

$$
x_{T}=\bar{x}+k \sigma_{n-1}
$$

where $\sigma_{n-1}=$ standard deviation of sample size $\mathrm{N}=\sqrt{\frac{\sum(x-\bar{x})^{2}}{N-1}}$

$\mathrm{K}=$ frequency factor $=\frac{y_{T}-\overline{y_{n}}}{s_{n}}$

in which, $y_{T}=$ reduced variate, a function of $T$ is given by $y_{T}=-\ln \ln \left(\frac{T}{T-1}\right)$

$\bar{y}_{n}=$ reduced mean, a function of sample size $N$

$S_{n}=$ reduced standard variate, a function of sample size $N$ 


\subsubsection{Log Pearson Type III Distribution Method [7]}

In this method, first variate is transformed into logarithmic form (base 10) and the transformed data is analyzed. If $\mathrm{x}$ is the variate of a random hydrologic series, then the series of $\mathrm{z}$ variates are formed where, $\quad \mathrm{z}=\log \mathrm{x}$

Then, $\quad z_{T}=\bar{z}+k \sigma_{z}$

where, $\mathrm{k}=$ function of $\mathrm{C}, \mathrm{T}=\mathrm{a}$ frequency factor which is function of recurrence interval $\mathrm{T}$ and coefficient of skewness $\mathrm{C}$

$$
\begin{aligned}
& \sigma_{z}=\sqrt{\frac{\sum(z-\bar{z})^{2}}{N-1}} \\
& \mathrm{C}=\text { coefficient of skewness of variate } \mathrm{z}=\frac{n \sum(z-\bar{z})^{\mathrm{a}}}{(n-1)(n-2) \sigma_{z}{ }^{a}}
\end{aligned}
$$

where $\bar{z}=$ mean of $\mathrm{z}, \mathrm{n}=$ sample size $=$ number of years of record, on calculating $z_{T}, x_{T}$ is calculated.

\subsubsection{B.D. Richard's Method [3]}

B. D. Richard's method may be used for flood estimation using rainfall and basin characteristics. The method, which has been comprehensively used in Mahakali Irrigation Project in western Nepal, consists of computing the flood discharge $\mathrm{Q}$ in $\mathrm{m}^{3} / \mathrm{s}$ using the equation

$$
\mathrm{Q}=0.222 \mathrm{AIF}
$$

where, $\mathrm{A}$ is basin area in sq. $\mathrm{km}$., I is the rainfall intensity corresponding to the time of concentration $\mathrm{Tc}, \mathrm{F}$ is an aerial reduction factor given by

$$
\mathrm{F}=1.09352-0.6628 \ln (\mathrm{A})
$$

\subsection{Catchment Area Ratio Method [7]}

Topographic and meteorological characteristics of a drainage basin affect stream flow from the basin. The characteristics that are used in the study to evaluate the drainage-area ratio method are drainage area, main channel slope and precipitation. The drainage-area ratio method is based on the assumption that the stream flow or a site of interest can be estimated by multiplying the ratio of the drainage-area for the site of interest and the drainage area by the stream-flow for the nearby stream flow gauging station. Thus, drainage area ratio method is given by

$$
Q_{y}=1.24\left(\frac{A_{y}}{A_{x x}}\right)^{0.85} Q_{X} \text {, where } 1.24 \text { was coefficient adopted for our study. }
$$

\subsection{Hydrologic Engineering System- River Analysis System (HEC-RAS)}

HEC-RAS is a hydraulic model developed by the Hydrologic Engineering Center (HEC) of the U.S. Army Corps of Engineers. [8] HEC-RAS is a one-dimensional steady flow model, intended for computation of water surface profile. Modules for unsteady flow simulation and movable- 
boundary sediment transport calculations are scheduled to be included. The system is capable of modeling subcritical, supercritical, and mixed-flow regimes for streams consisting of a full network of channels, a dendritic system, or a single river reach.

\subsection{Geographical Information System (GIS)}

GISs are defined as computer systems GIS provides a setting in which to overlay data layers and perform spatial queries, and thus create new spatial data. The results can be digitally mapped and tabulated, facilitating efficient analysis and decision making. Structurally, GIS consists of a computer environment that joins graphical elements (points, lines, polygons) with associated tabular attribute descriptions. For example, in a GIS view of a river network, the graphical elements represent the location and shape of rivers, whereas attributes might describe the stream name, length, and flow rate.

\section{Methodology}

The various techniques, theoretical and computer models and the whole process applied in our project is discussed on this chapter. The brief summary of the procedure of our project is depicted through the flowchart given below:

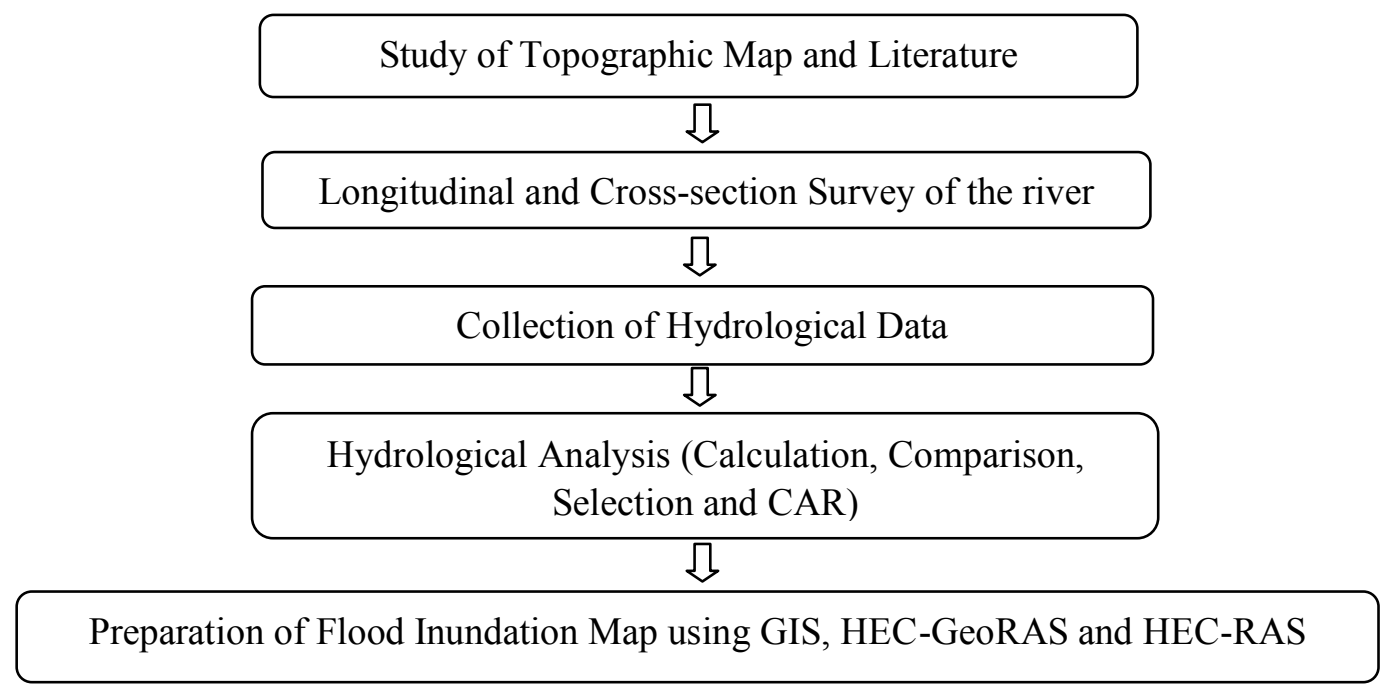

Fig. 2: Flowchart for Flood Inundation Mapping

\subsection{Field Survey}

A topographic survey of the study area- reach of Babai river, extending to 5 kilometers upstream from the outlet point $(28.171721 \mathrm{~N}, 82.067482 \mathrm{E})$ - was carried out. The survey was carried out for a week using Total Station, Fly Level, Measuring Tapes, and other basic survey instruments. The main objective of the survey was to gather data about the elevations of data on both sides of the river bank and present them as Triangulated Irregular Network (TIN) on a plot. 


\subsection{Hydrological Analysis}

High floods are required to be computed for HEC-RAS modeling as HEC-RAS needs discharge as input to find out flood inundation depths for various return periods. The flood flow analyses are carried out to obtain the worst flood that can occur in different time. Reliable flood estimates are essential for preparing flood hazard map of any basin. Hydrological data of the hydrological station near surveyed area (Chepang Station) existing in river basin were obtained from Department of Hydrology and Metrology (DHM), Government of Nepal. The flood discharge for return periods of 2,5,10,25,50,100,500 and 1000 years were calculated using ungauged methods, namely WECS- DHM Method, Fuller's Method, Rational Method and Modified Dickens method. Also, the discharges were calculated for the aforementioned return periods using gauged methods to estimate the discharge more accurately. Out of gauged methods - Log Pearson Type III Distribution Method and Gumbel's Method - the discharge computed from the first-mentioned method was selected as the discharge data was best fitted to Log Pearson Type III Distribution. The flood discharge for the outlet point of our study area was estimated using the Catchment Area Ratio Method. The inputs for the method i.e. catchment area of the station and our focus point were calculated using GIS.

\subsection{Preparation of Triangulated Irregular Network (TIN)}

The coordinate data obtained from survey was used for Triangulated Irregular Network generation. GIS was used to generate TIN which was used as input required in GeoRAS environment in order to prepare data sets required as input to the HEC-RAS simulation.

\subsection{Model Application}

PreRAS, postRAS and GeoRAS of HEC-GeoRAS extension in GIS environment were used for creating required data sets, making import file for model simulation in HEC-RAS. The preRAS option was used for creating required data sets for creating import file to HEC-RAS. Stream centerline, main channel banks (left and right), flow paths, and cross sections were created. Thus, after creating and editing required themes, RAS GIS import file was created. The import file created by HEC-GeoRAS was imported in Geometric Data Editor interface within HEC-RAS. All the required modification, editing was done at this stage. The flood discharge for different return periods were entered in steady flow data. Reach boundary conditions were also entered in this window. Then, water surface profiles were calculated in steady flow analysis window. After finishing simulation, RAS GIS export file was created. Water surface profiles were computed from one cross section to the next by solving the energy equation. The flow data were entered in the steady flow data editor for different return periods. Boundary condition was defined as normal depth for both upstream and downstream. Mixed flow analysis was done in steady flow analysis. Then after, water surface profiles were computed. The resulted was exported creating the RAS GIS export file. Then, In GIS using RAS GIS export file, floods and water depths were exported using Inundation Mapping option under RAS Mapping. 


\section{Results}

\subsection{Floods during Different Return Periods}

The flood discharge for different return periods were calculated using various methods, and are listed in the table below. The assessment of flood discharges indicate that the peak discharge is increasing with increase in duration of return period. B.D. Richard's Method gave the highest flood discharge for return periods of 2, 5, 10, 25, 50, 100 and 500 years, while for the return period of 1000 years Log Pearson method yielded the highest value of flood discharge: 10529.7 $\mathrm{m}^{3} / \mathrm{s}$.

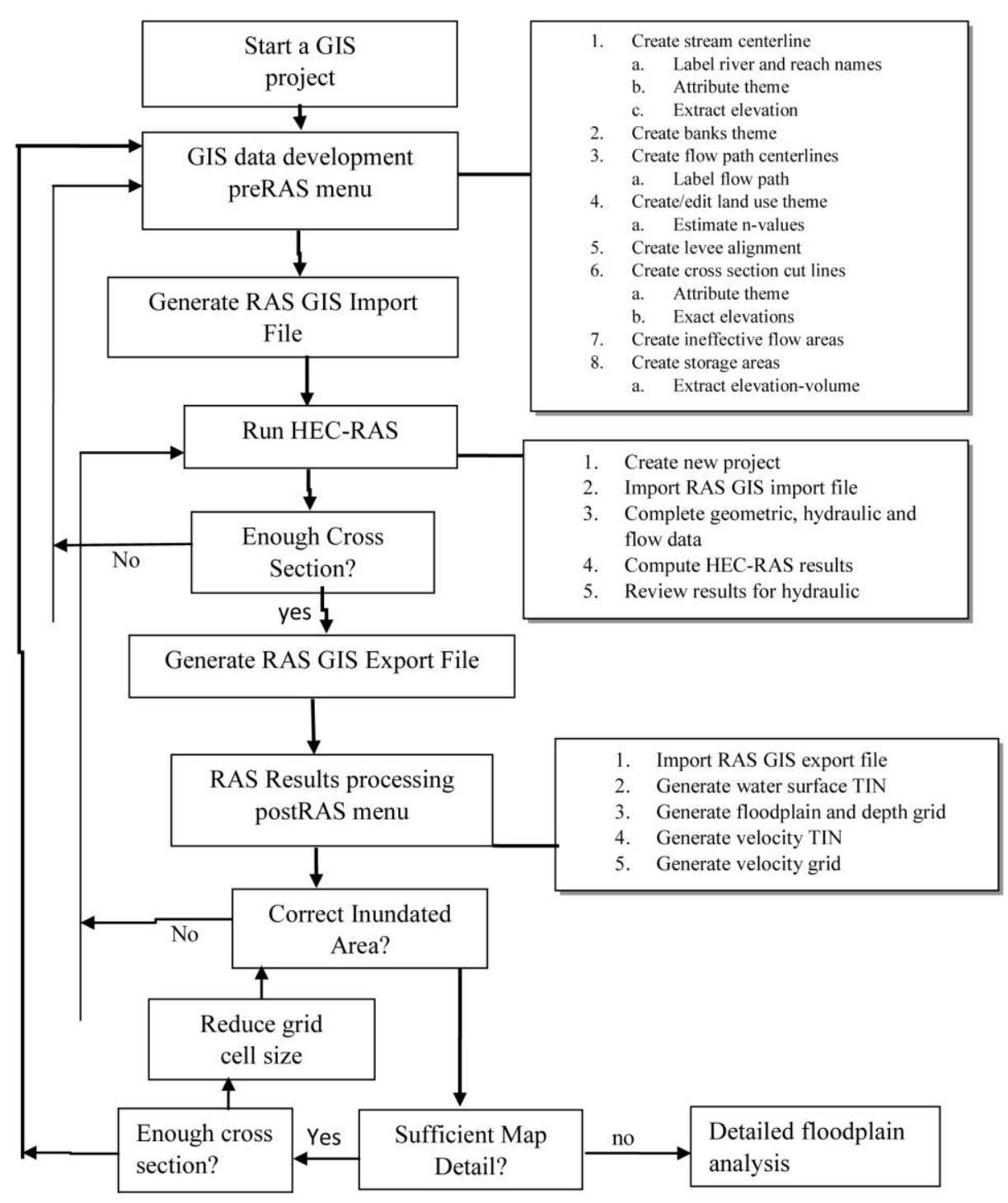

Fig. 3: Model Application Flowchart Source: USACE(2002) 


\subsubsection{Selection of Maximum Flow}

Considering gauged methods are more appropriate as they rely on actual discharge values and using Easy Fit 5.6 Professional, we found that Log Pearson III holds better in probability test of goodness of fit.

Table 2: Discharge for different return periods using different methods

\begin{tabular}{|c|c|c|c|c|c|c|c|}
\hline \multirow{2}{*}{$\begin{array}{l}\text { Return } \\
\text { Period } \\
\text { (Years) }\end{array}$} & \multicolumn{7}{|c|}{ Methods } \\
\hline & WECS & Rational & Fuller's & $\begin{array}{l}\text { B.D } \\
\text { Richard's }\end{array}$ & Dickens & Gumbel's & $\begin{array}{l}\text { Log } \\
\text { Pearson }\end{array}$ \\
\hline 2 & 962.893 & 486.809 & 1581.079 & 2727.521709 & 676.348 & 1477.888 & 1339.085 \\
\hline 5 & 1403.890 & 565.226 & 1986.729 & 3744.871871 & 1138.217 & 2618.159 & 1833.614 \\
\hline 10 & 1709.645 & 632.835 & 2293.591 & 4458.723353 & 1487.608 & 3373.118 & 3096.250 \\
\hline 25 & 2011.423 & 734.775 & 2699.240 & 5399.492328 & 1949.478 & 4327.010 & 4233.153 \\
\hline 50 & 2415.723 & 822.664 & 3006.102 & 6126.322154 & 2298.868 & 5034.662 & 5188.717 \\
\hline 100 & 2728.642 & 921.065 & 3312.965 & 6867.644386 & 2648.259 & 5737.088 & 6239.762 \\
\hline 500 & 3493.827 & 1197.354 & 4025.476 & 8662.801393 & 3459.520 & 6436.952 & 8442.829 \\
\hline 1000 & 3841.775 & 1340.573 & 4332.338 & 9464.015923 & 3808.910 & 7360.289 & 10529.700 \\
\hline
\end{tabular}

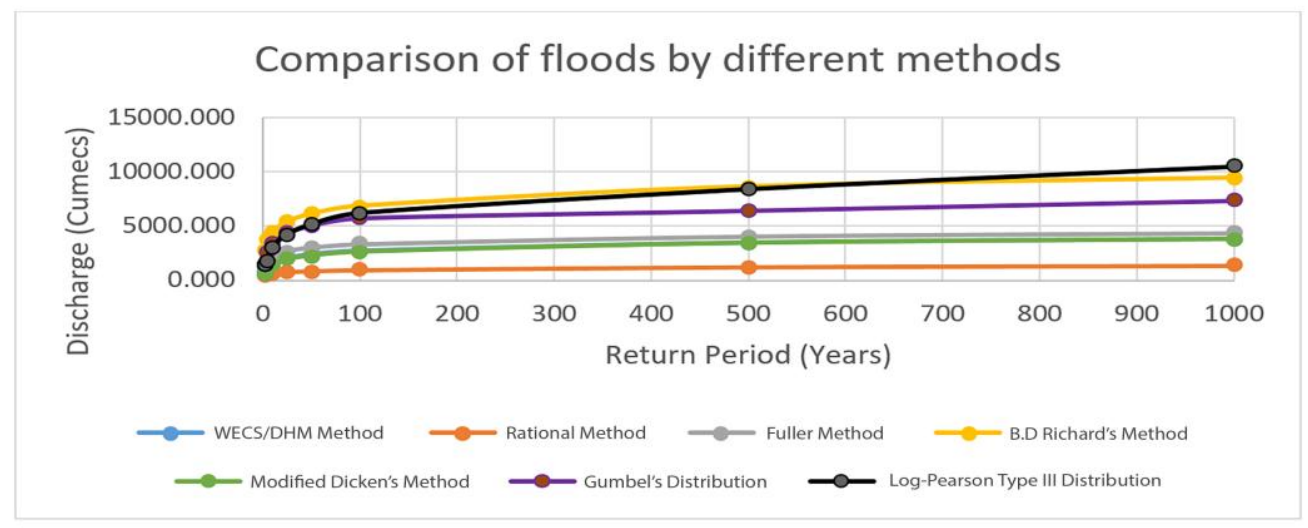

Fig. 4: Comparison of floods by different methods

Table 3: Fitting of gauged methods

\begin{tabular}{|r|l|r|r|r|r|r|r|}
\hline \multirow{2}{*}{ SN } & \multirow{2}{*}{ Distribution } & \multicolumn{2}{|c|}{ Kolmogorov Smirnov } & \multicolumn{2}{|c|}{ Anderson Darling } & \multicolumn{2}{c|}{ Chi-Squared } \\
\cline { 3 - 8 } & & \multicolumn{1}{|c|}{ Statistic } & \multicolumn{1}{|c|}{ Rank } & \multicolumn{1}{c|}{ Statistic } & \multicolumn{1}{c|}{ Rank } & \multicolumn{1}{c|}{ Statistic } & \multicolumn{1}{c|}{ Rank } \\
\hline 1 & Gumbel Min & 0.29182 & 2 & 4.1981 & 2 & 4.3495 & 2 \\
\hline 2 & Log-Pearson 3 & 0.11562 & 1 & 0.50298 & 1 & 1.0015 & 1 \\
\hline
\end{tabular}

\subsubsection{Discharge by Catchment Area Ratio Method}

From GIS, catchment area of hydrological station (Chepang) $=2611.835 \mathrm{~km}^{2}$ and catchment area of outlet $=1261.026 \mathrm{~km}^{2}$ 
Table 4: Corrected discharge using CAR

\begin{tabular}{|l|l|l|l|l|l|l|l|l|}
\hline T (Years) & 2 & 5 & 10 & 25 & 50 & 100 & 500 & 1000 \\
\hline $\mathrm{Q}\left(\mathrm{m}^{3} / \mathrm{s}\right)$ & 1339.085 & 1833.614 & 3096.25 & 4233.153 & 5188.717 & 6239.762 & 8442.829 & 10529.7 \\
\hline Q corrected $\left(\mathrm{m}^{3} / \mathrm{s}\right)$ & 775.607 & 1062.042 & 1793.369 & 2451.871 & 3005.341 & 3614.113 & 4890.145 & 6098.875 \\
\hline
\end{tabular}

\subsection{Inundation Maps for Different Return Periods}

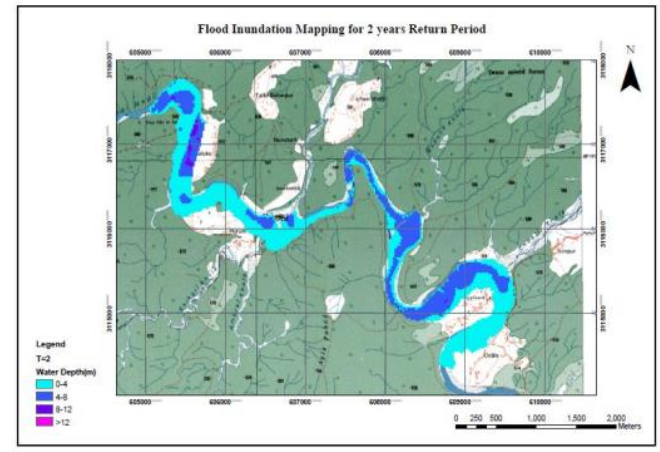

(a) $\mathrm{T}=2$ years

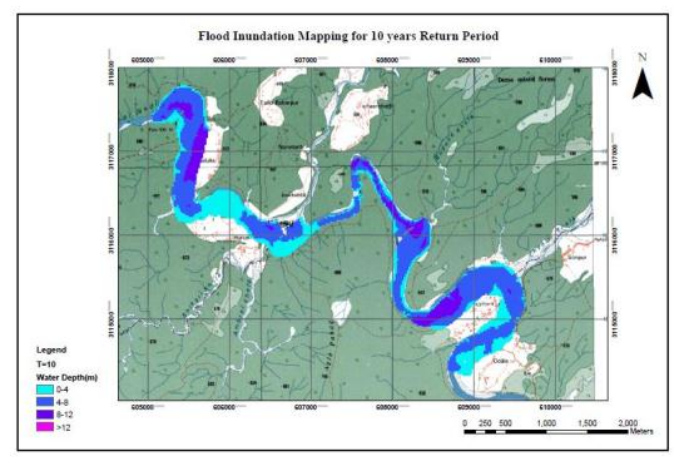

(c) $\mathrm{T}=10$ years

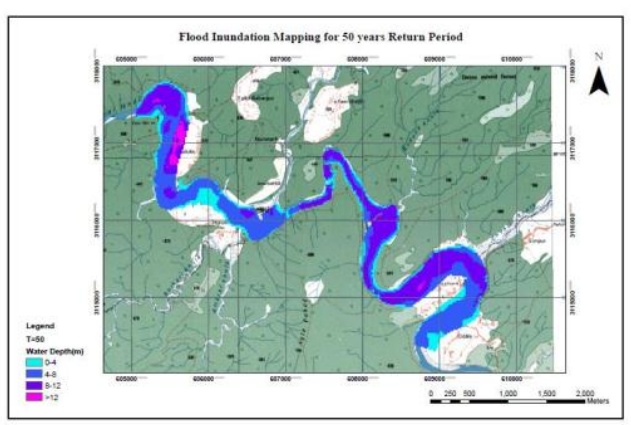

(e) $\mathrm{T}=50$ years

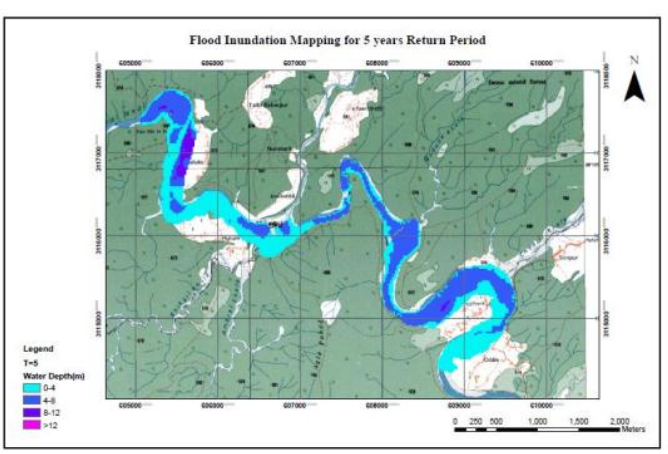

(b) $\mathrm{T}=5$ years

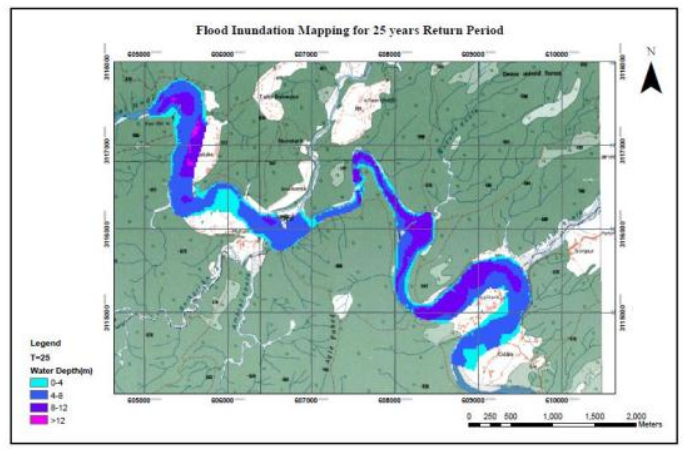

(d) $\mathrm{T}=25$ years

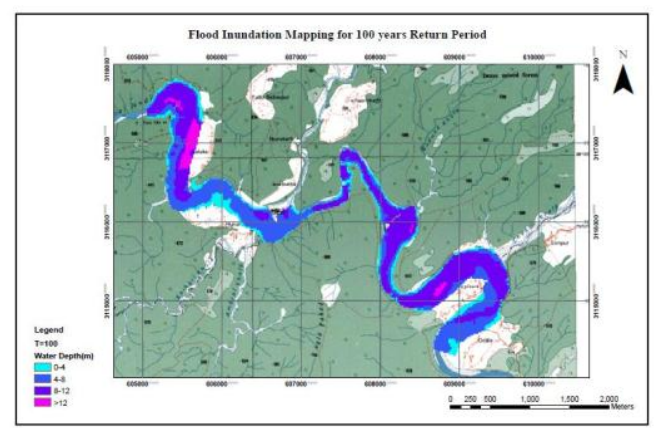

(f) $\mathrm{T}=100$ years 


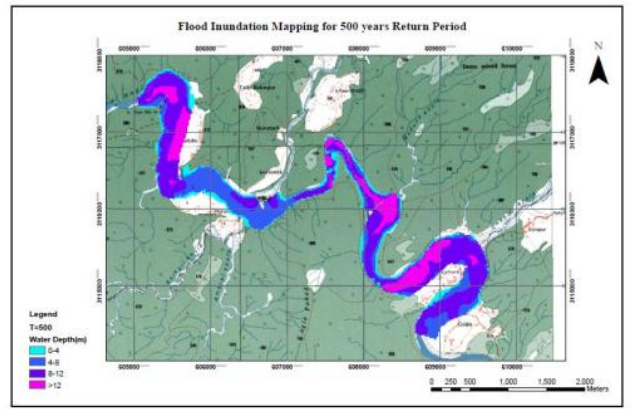

(g) $\mathrm{T}=500$ years

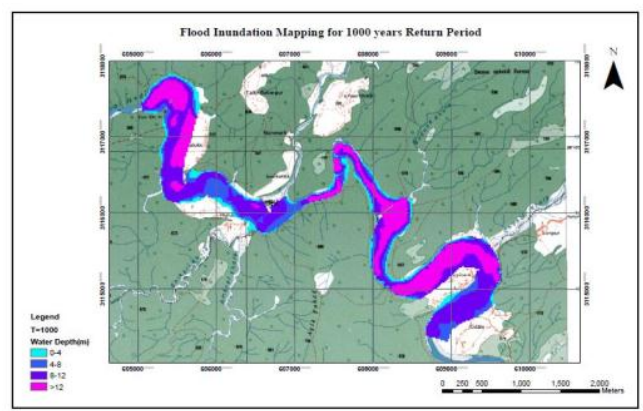

(h) $\mathrm{T}=1000$ years

Fig. 5: Inundation Maps for Different Return Periods

\subsection{Flood Vulnerability Analysis}

The vulnerable areas were calculated by intersecting the land use map of the study area polygon for each of the flood event being modeled. The land use area under the influence of modeled flood is summarized in the table 5 and 6 . The assessment of the flood areas indicate that large percentage (47 to $49 \%$ ) of vulnerable area belongs to agriculture category. From the table below, it is shown that the flooded area increased with increase in flooding intensity.

Table 5: Classification of flooded area according to land use vulnerability

\begin{tabular}{|c|c|c|c|c|c|c|c|c|c|}
\hline \multirow{2}{*}{ S.No. } & \multicolumn{9}{|c|}{ Total Vulnerable Area (ha.) } \\
\cline { 2 - 11 } & $\begin{array}{c}\text { Return } \\
\text { period }\end{array}$ & \multicolumn{2}{|c|}{2 Years } & \multicolumn{2}{|c|}{5 Years } & \multicolumn{2}{|c|}{10 Years } & \multicolumn{2}{|c|}{25 Years } \\
\cline { 2 - 11 } & Land use & Area & $\%$ & Area & $\%$ & Area & & Area & $\%$ \\
\hline 1 & Forest & 7.02 & 3.09 & 11.79 & 4.74 & 13.41 & 5.31 & 16.65 & 6.31 \\
\hline 2 & Shrub land & 1.17 & 0.51 & 1.08 & 0.45 & 1.35 & 0.53 & 1.35 & 0.51 \\
\hline 3 & Grassland & 2.97 & 1.31 & 3.6 & 1.51 & 4.05 & 1.60 & 4.23 & 1.60 \\
\hline 4 & Agriculture & 108.18 & 47.59 & 115.83 & 47.70 & 123.48 & 48.91 & 129.96 & 49.25 \\
\hline 5 & Barren Land & 1.26 & 0.55 & 1.26 & 0.53 & 1.26 & 0.50 & 1.26 & 0.48 \\
\hline 6 & Water Body & 106.74 & 46.95 & 107.13 & 45.07 & 108.9 & 43.14 & 110.43 & 41.85 \\
\hline & Total & 227.34 & 100.0 & 240.69 & 100.0 & 252.45 & 100.0 & 263.88 & 100.0 \\
\hline
\end{tabular}

Table 6: Classification of flooded area according to land use vulnerability

\begin{tabular}{|c|c|c|c|c|c|c|c|c|c|}
\hline \multirow{3}{*}{ S.No. } & \multicolumn{9}{|c|}{ Total Vulnerable Area (ha.) } \\
\cline { 2 - 12 } & $\begin{array}{c}\text { Return } \\
\text { period }\end{array}$ & \multicolumn{2}{|c|}{50 Years } & \multicolumn{2}{|c|}{100 Years } & \multicolumn{2}{|c|}{500 Years } & \multicolumn{2}{|c|}{1000 Years } \\
\cline { 2 - 12 } & Land use & Area & $\%$ & Area & $\%$ & Area & $\%$ & Area & $\%$ \\
\hline 1 & Forest & 19.26 & 7.06 & 22.32 & 8.00 & 27.99 & 9.63 & 32.22 & 10.69 \\
\hline 2 & Shrub land & 1.35 & 0.50 & 1.8 & 0.64 & 2.07 & 0.71 & 2.07 & 0.69 \\
\hline 3 & Grassland & 4.32 & 1.58 & 4.5 & 1.61 & 4.5 & 1.55 & 4.68 & 1.55 \\
\hline
\end{tabular}




\begin{tabular}{|c|c|c|c|c|c|c|c|c|c|}
4 & Agriculture & 134.91 & 49.47 & 137.34 & 49.21 & 142.11 & 48.87 & 146.25 & 48.54 \\
\hline 5 & Barren Land & 1.26 & 0.46 & 1.53 & 0.55 & 1.53 & 0.53 & 1.44 & 0.48 \\
\hline 6 & Water Body & 111.6 & 40.92 & 111.6 & 39.99 & 112.59 & 38.72 & 114.66 & 38.05 \\
\hline & Total & 272.7 & 100.0 & 279.09 & 100.0 & 290.79 & 100.0 & 301.32 & 100.0 \\
\hline
\end{tabular}

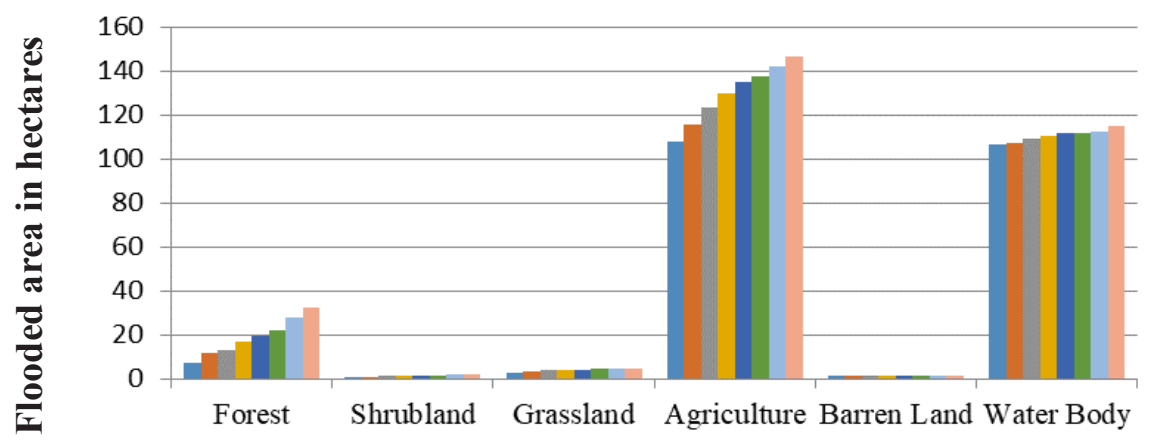

\section{Return period}

2 Years

5 Years

- 10 Years

25 Years

- 50 Years

100 Years

500 Years

1000 Years

\section{Land use}

Fig. 6: Graph showing flooded areas for different return periods

\subsection{Change in Maning's Constant (n)}

As the Manning's $\mathrm{n}$ taken in the computations were adopted from the literature review, sensitivity analysis was done to analyze the effects of change in Manning's $n$ on the area inundated. Table 7 and 8 presents the percentage change in area inundated when Maning's $n$ is increased by $10 \%$ and kept same on all banks viz. LOB (Left of Bank), ROB (Right of Bank) and Ch (Channel) respectively.

Table 7: Comparison of change in area Inundated when Maning's $n$ increased by $10 \%$ and kept same in banks and channels

\begin{tabular}{|c|c|c|c|c|c|c|c|}
\hline $\begin{array}{c}\text { Return } \\
\text { Period } \\
(\mathbf{T})\end{array}$ & \multicolumn{3}{|c|}{$\begin{array}{c}\text { Maning's } \\
\mathbf{N}\end{array}$} & $\begin{array}{c}\text { Change in } \\
\text { Maning 's } \\
n \\
\Delta n \mathbf{~ \% )}\end{array}$ & $\begin{array}{c}\text { Change in } \\
\text { Inundated } \\
\text { Area } \Delta A(\%)\end{array}$ & $\begin{array}{c}\text { Maning's n } \\
\text { in both } \\
\text { banks and } \\
\text { channels }\end{array}$ & $\begin{array}{c}\text { Change in } \\
\text { Inundated } \\
\text { Area } \Delta A(\%)\end{array}$ \\
\hline & LOB & Ch & ROB & & & & \\
\hline 2 & 0.040 & 0.038 & 0.040 & 0.038 & 0.54941 & 0.038 & -0.00178 \\
\hline 5 & 0.040 & 0.038 & 0.040 & 0.038 & 0.85241 & 0.038 & -0.00201 \\
\hline 10 & 0.040 & 0.038 & 0.040 & 0.038 & 0.49790 & 0.038 & -0.00306 \\
\hline 25 & 0.040 & 0.038 & 0.040 & 0.038 & 0.71798 & 0.038 & -0.00450 \\
\hline 50 & 0.040 & 0.038 & 0.040 & 0.038 & 0.52307 & 0.038 & -0.00310 \\
\hline 100 & 0.040 & 0.038 & 0.040 & 0.038 & 0.63854 & 0.038 & -0.00332 \\
\hline 500 & 0.040 & 0.038 & 0.040 & 0.038 & 0.69537 & 0.038 & -0.00203 \\
\hline 1000 & 0.040 & 0.038 & 0.040 & 0.038 & 0.75648 & 0.038 & -0.00275 \\
\hline
\end{tabular}




\section{Conclusions and Recommendations}

\subsection{Conclusion}

This study presents an approach in the preparation of 'Flood Inundation Map of Babai basin' with the application of steady flow models and GIS. The major tools/models used in this method are one-dimensional numerical model HEC-RAS and GIS for spatial data processing and HECGeoRAS extension for interfacing between HEC-RAS and GIS. This study can be concluded as follows:

1. The assessment of flood vulnerability with relation to the return period of floods and their water depth. The examination of the flood water depth shows that all of the areas under flooding have water depth less than $18 \mathrm{~m}$.

2. The assessment of the vulnerability was made with regard to the land use pattern in the flood areas. The assessment of the area indicates that a large percentage (47 to $49 \%$ ) of vulnerable area is agricultural land and followed by water body and forest, comprising (38 to 46\%) and (3 to $10 \%$ ) respectively.

3. In first analysis, the manning's $n$ was increased by $10 \%$ from 0.05 in left and right banks and 0.0384 in the channel portion to 0.055 and 0.04224 . The percent change in area inundated was limited to $0.63 \%$. In second analysis, the manning's $n$ was kept 0.0384 for both channel and bank sections. The maximum percent change in area inundated was a decrease by $0.0045 \%$. Hence, it can be inferred that discrepancy in actual Manning's n of survey site and that adopted from the literature review does not affect area inundated significantly.

\subsection{Recommendation}

The study was conducted under major constraint of limited availability. Therefore, following recommendations are made for the further studies in the future.

1. Land use Pattern and Structures: Present scenario of land use pattern can be incorporated in further study. Land use pattern of 2010 provided by ICIMOD was used in analysis. Effect of the constructed structures of the river on the flood can be taken into account in further research.

2. Flood Hazard Mapping: This study can be extended to flood hazard mapping incorporating different population and statistic data.

3. Others: Classification of population according to vulnerable groups can be incorporated in further study.

Acknowledgement: We gratefully acknowledge Department of Hydrology and Metrology, Government of Nepal from where discharge data for Chepang station near our study site was obtained. We would like to thank to Dr. Raghunath Jha for aiding in software GIS during our project work and clearing our queries. 


\section{References}

[1] Ackerman C (2009), HEC-GeoRAS-GIS Tools for Support of HECRAS Using ArcGIS, User's Manual. US Army Corps of Engineers-Hydrologic Engineering Center (HEC).

[2] Azouagh A, Bardai RE, Hilal I and Messari JS (2018), Integration of GIS and HEC-RAS in Modelling of Martil River, European Scientific Journal, 14(12):130-142.

[3] Department of Electricity Development, Ministry of Water Resources, Government of Nepal (2006), Design Guidelines for Headworks of Hydropower Projects.

[4] Department of Water Induced Disaster Prevention (DWIDP) (2016), Flood Hazard Mapping and Preliminary Preparation of Flood Risk Management Projects, Technical Assistance Consultant's Report.

[5] Nadzri M, Halim MEA and Roslan N (2009), Integration of GIS and hydraulic model for flood inundation mapping in Sungai Basin., Research Institute For Sustainability and Enviroment(RISE), Universiti Teknologi Malayasia.

[6] National Adaptation Planning of Action (NAPA) (2011), GIS based Flood Hazard Mapping and Vulnerability Assessment of People due to Climate Change: A case study from Kankai watershed, Eastern Nepal.

[7] Subramanya K (2013), Engineering Hydrology (Fourth Edition), TATA McGRAW Hill, New Delhi.

[8] US Army Corps of Engineers Hydrologic Engineering Center (USACE) (2009), HEC- GeoRAS GIS Tools for Support of HEC-RAS using ArcGIS, User's Manual. Version 4.2.

[9] US Department of Interior, U.S Geological Survey (1998), Publication of U.S Geological Survey.

[10] WECS/DHM, Department of Hydrology and Meteorology and Water and Energy Commission Secretariat, Kathmandu (1990), Methodologies for Estimating Hydrological Characteristics for Ungauged Location in Nepal. 